\title{
Is Food Processing Industry A Promise To The Growth And Sustanability Of New Entrepreneurs In India? An Account of Evidence from the Existing Realities
}

\author{
Dr. B.Sudhakar Reddy
}

World Commission on Environment and Development was created in1983. Popularly known as Brundtland Commission (1983)2, it described sustainable development as "development that meets the needs of the present without compromising the ability of future generations to meet their own needs". Drawing from the definition of sustainable development, Food processing industry has emerged recently as a sun rise industry and promoting entrepreneurial activities to a considerable extent. Business economists and practicing entrepreneurs are of the opinion that it is going to be a hub of new entrepreneurial activities in the near future. A strong and effective food processing sector plays a significant role in diversification of agricultural activities improving value addition opportunities and creating surplus for export of agro food products. The most important point in the food processing industry is that a substantial portion being rural based it has a very high employment potential with significantly lower investment. The fruits and vegetable farming for processing is not only employment intensive, but also enhances the gross as well as net return of the farmers. Further, food processing industry generates new demand as the farm sector for more and different agricultural outputs. On the other hand, the development of these industries would relax wage goods constraints to economic growth by enhancing the supply of their products. Post harvesting and food processing technology enhances per capita food availability from a unit arable land and other resources by preventing avoidable post harvest losses and addition value to the agro products. It also creates opportunities for employment and income generation. Rural people process their foods in different ways and for different reasons. The most obvious need for processing is to make a food edible. People also process food to reduce losses, especially in the case foods that decay quickly. Losses during storage of food stuffs can be reduced by proper pre processing. Effective storage is the best food security for the poor people. Food processing offers use value for surpluses that might otherwise be wasted. After realizing the present and future potential for enterprising activities, the present study intends to obtain empirical conformity about the scope for sustainable growth of entrepreneurial activities through food processing industry in India.

\section{OBJECTIVES OF THE PAPER}

1. To examine whether food processing industry in India can be a potential hub for the sustainable growth of new entrepreneurial opportunities or not?

2. To test whether the development of new entrepreneurial opportunities in food processing industry is activity biased or not?

Towards end of the objectives, 90 practicing entrepreneurs of food processing industry in Andhra Pradesh are selected mostly by adhering to the principles of stratified random sampling. The sample composition is as followed.

Table-1

The composition of sample practicing entrepreneurs in food processing industry

\begin{tabular}{|l|l|l|}
\hline S1.No & Type of unit & $\begin{array}{l}\text { Number } \\
\text { entrepreneurs }\end{array}$ \\
\hline 1 & Fruits and vegetables & 37 \\
\hline 2 & Milk & 7 \\
\hline 3 & Soft drinks & 3 \\
\hline 4 & Fish products & 13 \\
\hline 5 & Meat and meat products & 2 \\
\hline 6 & Eggs & 3 \\
\hline 7 & Rice & 17 \\
\hline 8 & Walnuts & 8 \\
\hline & & \\
\hline
\end{tabular}

\footnotetext{
- Associate Professor, Department of Economics, Osmania University, Hyderabad, Andhra Pradesh.
} 
Source: primary data

Table-1 shows the distribution of the sample respondents by their line of activity. It is found that 41.1 percent of activities belonged to fruits and vegetables category, followed by 14.4 percent are from fish products, 18.9 percent from rice, 7.8 percent from milk, 8.9 percent from walnuts, 3.3 percent from soft drinks, 3.3 percent from eggs and 2.2 percent from meat and meat products.

\section{MAJOR FINDINGS}

Table-2

New entrepreneurial opportunity-Phenomenal growth of urbanization

\begin{tabular}{|c|c|c|c|}
\hline Phenomenal growth of urbanization & Frequency & Percent & Cumulative Percent \\
\hline Yes & 59 & 65.6 & 65.6 \\
\hline No & 31 & 34.4 & 100.0 \\
\hline Total & 90 & 100.0 & \\
\hline
\end{tabular}

\section{Source: primary data}

Table-2 refers to the distribution of the sample respondents by their perceptions about phenomenal growth of urbanization as a determinant of new entrepreneurial opportunities in food processing industry. It is observed that 65.6percent of the entrepreneurs have perceived new entrepreneurial opportunities in the area of food processing industry due to phenomenal growth of urbanization and 34.4 percent of the respondents did not subscribe to this view.

Table-3

\begin{tabular}{|c|c|c|c|}
\hline Improved standard of living & Frequency & Percent & Cumulative Percent \\
\hline Yes & 51 & 56.7 & 56.7 \\
\hline No & 39 & 43.3 & 100.0 \\
\hline Total & 90 & 100.0 & \\
\hline
\end{tabular}

Source: primary data

Table-3 refers to the distribution of the sample respondents by their perceptions about improved standard of living as a determinant of new entrepreneurial opportunities in food processing industry. It is observed that 56.7 percent of the entrepreneurs have perceived new entrepreneurial opportunities in the area of food processing industry due to improved standard of living and 43.3 percent of the respondents did not subscribe to this view.

Table-4

New entrepreneurial opportunity-Increasing convenience needs

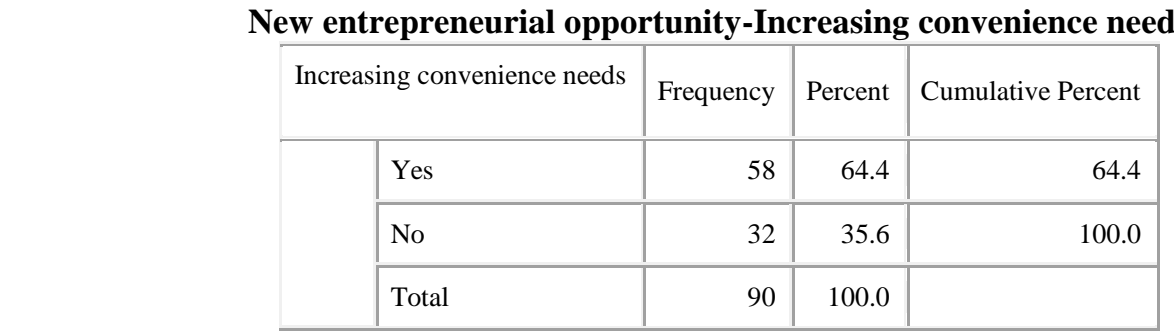

\section{Source: primary data}

Table-4 refers to the distribution of the sample respondents by their perceptions about increasing convenience needs as a determinant of new entrepreneurial opportunities in food processing industry. It is observed that 64.4 percent of the entrepreneurs have perceived new entrepreneurial opportunities in the area of food processing industry due to increasing convenience needs and 35.6 percent of the respondents did not subscribe to this view. 
Table-5

New entrepreneurial opportunity-Sustainable business

\section{Source: primary data}

\begin{tabular}{|c|c|c|c|}
\hline Sustainable business & Frequency & Percent & Cumulative Percent \\
\hline Yes & 73 & 81.1 & 81.1 \\
\hline No & 17 & 18.9 & 100.0 \\
\hline Total & 90 & 100.0 & \\
\hline
\end{tabular}

Table- 5 refers to the distribution of the sample respondents by their perceptions about sustainable business as a determinant of new entrepreneurial opportunities in food processing industry. It is observed that 81.1 percent of the entrepreneurs have expected new entrepreneurial opportunities in the area of food processing industry due to sustainable business and 18.9 percent of the respondents did not subscribe to this view.

Table-6

New entrepreneurial opportunity-Sunrise industry

New entrepreneurial opportunity-Sunrise industry
\begin{tabular}{|l|r|r|r|r|}
\hline Sunrise industry & Frequency & Percent & Cumulative Percent \\
\hline Yes & 82 & 91.1 & 91.1 \\
\hline No & 8 & 8.9 & 100.0 \\
\hline Total & 90 & 100.0 & \\
\hline
\end{tabular}

Source: primary data

Table-6 refers to the distribution of the sample respondents by their perceptions about sunrise industry as a determinant of new entrepreneurial opportunities in food processing industry. It is observed that 91.1 percent of the entrepreneurs have expected new entrepreneurial opportunities in the area of food processing industry due to sunrise industry status and 8.9 percent of the respondents did not subscribe to this view.

Table-7

New entrepreneurial opportunity-Demand potential

\begin{tabular}{|c|c|c|c|}
\hline Demand potential & Frequency & Percent & Cumulative Percent \\
\hline Yes & 69 & 76.7 & 76.7 \\
\hline No & 21 & 23.3 & 100.0 \\
\hline Total & 90 & 100.0 & \\
\hline
\end{tabular}

Source: primary data

Table-7 refers to the distribution of the sample respondents by their perceptions about demand potential as a determinant of new entrepreneurial opportunities in food processing industry. It is observed that 76.7 percent of the entrepreneurs have expected new entrepreneurial opportunities in the area of food processing industry due to demand potential and 23.3 percent of the respondents did not subscribe to this view.

Table-8

New entrepreneurial opportunity-Better future

\begin{tabular}{|c|c|c|c|}
\hline Better future & Frequency & Percent & Cumulative Percent \\
\hline Yes & 61 & 67.8 & 67.8 \\
\hline No & 29 & 32.2 & 100.0 \\
\hline Total & 90 & 100.0 & \\
\hline
\end{tabular}

Source: primary data

Table- 8 refers to the distribution of the sample respondents by their perceptions about better future as a determinant of new entrepreneurial opportunities in food processing industry. It is observed that 67.8 percent of 
the entrepreneurs have expected new entrepreneurial opportunities in the area of food processing industry due to better future and 32.2 percent of the respondents did not subscribe to this view.

Table-9

New entrepreneurial opportunity-State's initiatives

Source: primary data

\begin{tabular}{l|r|r|r|r|}
\hline \multicolumn{2}{|l|}{ State's initiatives } & Frequency & Percent & Cumulative Percent \\
\hline Yes & 61 & 67.8 & 67.8 \\
\hline No & 29 & 32.2 & 100.0 \\
\hline Total & 90 & 100.0 & \\
\hline
\end{tabular}

Table-9 refers to the distribution of the sample respondents by their perceptions about self actualization as a determinant of new entrepreneurial opportunities in food processing industry. It is observed that 67.8 percent of the entrepreneurs have new entrepreneurial opportunities in the area of food processing industry due to state initiatives and 32.2 percent of the respondents did not subscribe to this view.

Table-10

Testing the Null hypothesis (Ho) by using Chi-Square statistic between line of activity and the determinants of the growth of new entrepreneurial activities

\begin{tabular}{|l|l|l|}
\hline Sl.No & Determinants of the growth of new entrepreneurial activities & DF=7, LOS $=0.05$ \\
\cline { 3 - 3 } & & Line of activity \\
\hline 1 & phenomenal growth of urbanization & Ho not rejected \\
\hline 2 & Improved standard of living & Ho not rejected \\
\hline 3 & Increasing convenience needs & Ho not rejected \\
\hline 4 & Sustainable business & Ho not rejected \\
\hline 5 & Sunrise industry & Ho not rejected \\
\hline 6 & Demand potential & Ho not rejected \\
\hline 7 & Better future & Ho rejected \\
\hline 8 & State's initiatives & Ho not rejected \\
\hline
\end{tabular}

\section{Source: primary data}

Table-10 shows that the relationship between the line of activity and the perceptions of practicing entrepreneurs in food processing industry in Andhra Pradesh about food processing industry as a hub for the development of new entrepreneurial class and enterprising activities is found to be statistically independent except with reference to demand potential.

It is concluded that food processing industry will be an emerging sector for the growth of new enterprises and entrepreneurs as endorsed by the majority of the practicing entrepreneurs in the same field.

\section{BIBLIOGRAPHY}

[1]. Acharya, S. S. (1997), 'Agriculture-Industry linkages, public policy and some areas of Concern Agricultural Economics research Review, Vol.10, No.2, pp. 162-175.

[2]. Arora, V. P. S (2002), Food processing industry in India: a SWOT analysis. INDIAN JOURNAL OF AGRICULTURE MARKETING, 16(3) (sept-Dec), pp 35-40.

[3]. Badatya, K. C. (2003), 'Income and employment effects of small-scale agro-processing Activities', Indian journal of agricultural economics, vol. 58 , No. 3 .

[4]. Chandrasekhara Rao, N. (2009), Nature of employment in the food processing sector. ECONOMIC AND POLITICAL WEEKLY, 44(17): PP 109- 55.

[5]. Dasai, Bhupat M and Nambodiri, N. V (1992), development of food processing industries. ECONOMIC AND POLITICAL WEEKLY, 27(13), (March-28), 2705-2722. 